\title{
Technical Note: Hydrocortisone as a Performance Verification Test Reference Standard for In Vitro Release Testing
}

\author{
Ryan R. Klein, Jenna L. Bechtel, Kris Burchett, and Kailas D. Thakker* \\ Analytical Solutions, Inc., Durham, NC, 27713
}

\section{INTRODUCTION}

$\mathrm{O}$ ver the last two decades, in vitro release testing (IVRT) using vertical diffusion cells has become the standard approach for assessing the performance of topical semisolid dosage forms. More recently, studies have indicated that IVRT should be considered as a performance verification test for these types of dosage forms (1). Hauck et al. have further suggested that a $1 \%$ hydrocortisone cream be considered as a reference standard for such verification testing, despite its high variability in IVRT studies, because of the consistent release-rate profiles that have been observed and reported since its development more than two decades ago (1-4). Further examination of the potential sources of this high variability is warranted if hydrocortisone is to be established as the reference standard for IVRT verification testing.

Membrane soaking has been reported as an essential procedure for studying the in vitro release of hydrocortisone from ointment formulations but unnecessary for creams and lotions (3). Despite being unnecessary for certain topical formulations, a soaking step is often included in IVRT experiments as a way to standardize protocols between laboratories since it is required to evaluate ointments (1). Typically, a solution of isopropyl myristate (IPM), a surfactant reported to be representative of skin lipids (5), and ethoxylated aliphatic amine (ethomeen) is used to soak the membranes for up to one hour before the experiment.

Studies have been carried out to evaluate the impact of soaking a polysulfone membrane on the in vitro release rate of hydrocortisone from a $1 \%$ hydrocortisone cream. Figure 1 and Table 1 indicate that soaking the membrane for thirty minutes before initiating the experiment leads to a three-fold increase in the release rate of hydrocortisone. These data indicate that although soaking the membrane is not necessary to monitor the release of hydrocortisone, the inclusion of the soaking step enhances release. Further, the effect of adding ethomeen to the soaking solution is minimal, suggesting that this component may not be critical for enhancing the release rate of hydrocortisone.

The sensitivity of hydrocortisone release rate to minor variations in temperature has also been assessed. Figure 2 and Table 1 illustrate the importance of maintaining a constant and accurate temperature during the IVRT

${ }^{*}$ Corresponding author experiment. A reduction in temperature by just one degree (i.e., $32{ }^{\circ} \mathrm{C}$ to $31^{\circ} \mathrm{C}$ ) leads to a small but significant change in the measured release rate of hydrocortisone as assessed by the Wilcoxon Rank Sum or Mann-Whitney statistical test. Therefore, care should be taken to minimize heat loss during IVRT experiments as they are typically performed at $32^{\circ} \mathrm{C}$. These results warrant additional work to evaluate the sensitivity of hydrocortisone release rate to common experimental parameters within an IVRT study to better understand the reported variability.

\section{MATERIALS AND METHODS IVRT Analysis}

Six Franz diffusion cells were used for each experiment. Approximately $300-400 \mathrm{mg}$ of a $1 \%$ hydrocortisone cream was applied to the Teflon wafer of the donor chamber, which was completely occluded by covering the cream with an opaque glass disk. The receiving medium was 30:70 ethanol/water.Tuffryn membranes were used as the barrier and were either unsoaked or soaked for thirty minutes in IPM or IPM with $15 \%$ ethomeen. The temperature of the diffusion cells was maintained at the indicated temperatures. At 1, 2, 3, 4, and $6 \mathrm{~h}, 200 \mu \mathrm{L}$ of sample was withdrawn and replenished with fresh, prewarmed media. Hydrocortisone concentration in the IVRT samples was determined using the HPLC method

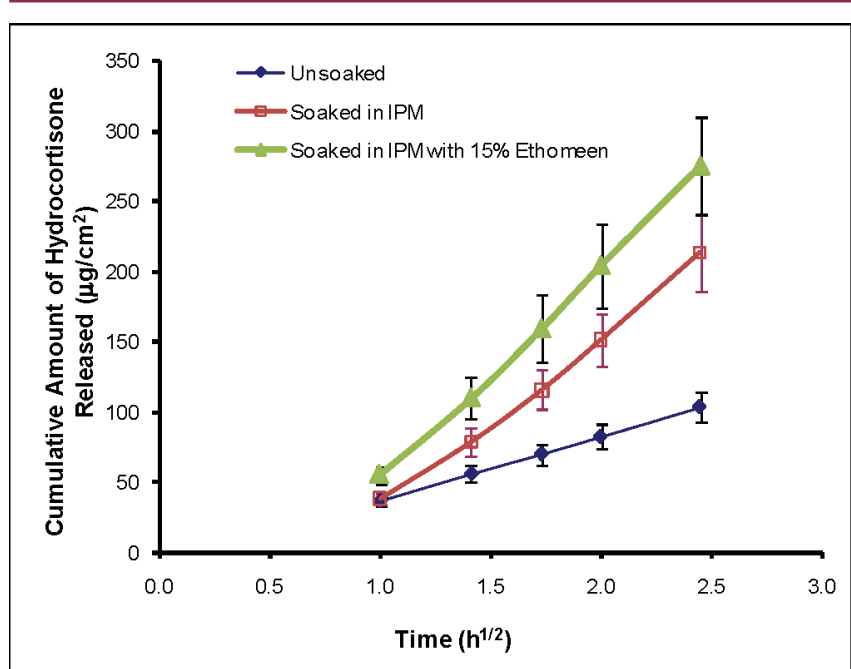

Figure 1. Hydrocortisone release profiles from Cortaid cream with different membrane-soaking conditions at $32^{\circ} \mathrm{C}(n=6)$. 


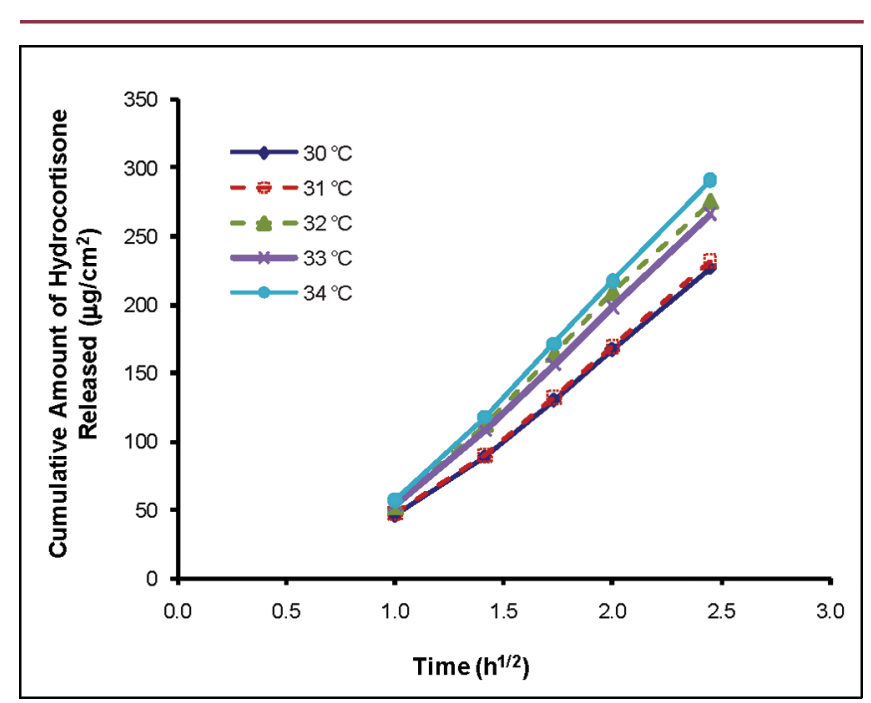

Figure 2. Hydrocortisone release profiles from Cortaid cream at different temperatures with membranes soaked in IPM with 15\% ethomeen for $30 \mathrm{~min}$ $(n=6)$. Error bars have been omitted for clarity.

Table 1. Average Release Rates for Hydrocortisone from Cortaid Cream Under Different Conditions $(n=6)$

\begin{tabular}{|c|c|c|c|c|}
\hline $\begin{array}{l}\text { Soaking } \\
\text { Condition }\end{array}$ & $\begin{array}{c}\text { Temperature } \\
\left({ }^{\circ} \mathrm{C}\right)\end{array}$ & $\begin{array}{c}\text { Hydrocortisone } \\
\text { Release Rate } \\
\left(\mu \mathrm{g} / \mathrm{cm}^{2} / \mathrm{min}^{1 / 2}\right)\end{array}$ & $\begin{array}{l}\text { Standard } \\
\text { Deviation }\end{array}$ & $\%$ RSD \\
\hline Unsoaked & 32 & 5.96 & 0.66 & 11 \\
\hline Soaked in IPM & 32 & 15.7 & 2.1 & 13 \\
\hline $\begin{array}{l}\text { Soaked in IPM } \\
\text { with } 15 \% \\
\text { ethomeen }\end{array}$ & 32 & 19.7 & 2.8 & 14 \\
\hline $\begin{array}{l}\text { Soaked in IPM } \\
\text { with } 15 \% \\
\text { ethomeen }\end{array}$ & 30 & 16.3 & 1.3 & 8.0 \\
\hline $\begin{array}{l}\text { Soaked in IPM } \\
\text { with } 15 \% \\
\text { ethomeen }\end{array}$ & 31 & 16.6 & 1.4 & 8.2 \\
\hline $\begin{array}{l}\text { Soaked in IPM } \\
\text { with } 15 \% \\
\text { ethomeen }\end{array}$ & 32 & 20.0 & 3.6 & 18 \\
\hline $\begin{array}{l}\text { Soaked in IPM } \\
\text { with } 15 \% \\
\text { ethomeen }\end{array}$ & 33 & 19.0 & 0.75 & 4.0 \\
\hline $\begin{array}{l}\text { Soaked in IPM } \\
\text { with } 15 \% \\
\text { ethomeen }\end{array}$ & 34 & 21.0 & 1.9 & 8.9 \\
\hline
\end{tabular}

Table 2. HPLC Gradient Profile

\begin{tabular}{lll}
\hline Time (min) & \% A & \% B \\
\hline 0 & 75 & 25 \\
\hline 2.5 & 75 & 25 \\
\hline 6.5 & 0 & 100 \\
\hline 7.5 & 0 & 100 \\
\hline 8 & 75 & 25 \\
\hline 10 & 75 & 25 \\
\hline
\end{tabular}

described below. The cumulative amount of hydrocortisone released was calculated and plotted against the square root of time to determine the release rate in each diffusion cell.

\section{HPLC Analysis}

Hydrocortisone concentration in the IVRT samples was determined by reversed-phase HPLC with UV detection using a Shimadzu liquid chromatography system. Separation was performed on a Thermo Hypersil BDS C18 column, $4.6 \times 100 \mathrm{~mm}, 5 \mu \mathrm{M}$, maintained at $40^{\circ} \mathrm{C}$. Mobile phase $A$ was water. Mobile phase $B$ was acetonitrile. $A$ ten-minute gradient (Table 2) was used to elute hydrocortisone with a flow rate of $1.0 \mathrm{~mL} / \mathrm{min}$ and UV detection at $242 \mathrm{~nm}$. Injection volume was $20 \mu \mathrm{L}$. Samples were kept at ambient temperature during analysis.

\section{REFERENCES}

1. Hauck, W.W.; Shah, V.P.; Shaw, S.W.; Ueda, C.T. Reliability and reproducibility of vertical diffusion cells for determining release rates from semisolid dosage forms. Pharm. Res. 2007, 24 (11), 2018-2024.

2. Shah, V. P.; Elkins, J.; Lam, S.-Y.; Skally, J. P. Determination of in vitro drug release from hydrocortisone creams. Int. J.Pharm. 1989, 53 (1), 53-59.

3. Shah, V. P.; Elkins, J.; Hanus, J.; Noorizadeh, C.; Skelly, J.P. In vitro release of hydrocortisone from topical preparations and automated procedure. Pharm. Res. 1991, 8 (1), 55-59.

4. Shah, V. P.; Elkins, J. S.; Shaw, S.; Hanson, R. In vitro release: Comparative evaluation of vertical diffusion cell system and automated procedure. Pharm. Dev. Technol. 2003, 8 (1), 97-102.

5. Poulsen, B. J.; Young, E.; Coquilla, V.; Katz, M. Effect of topical vehicle composition on the in vitro release of fluocinolone acetonide and its acetate ester.J.Pharm. Sci. 1968, 57 (6), 928-933. 